Article

\title{
CSR Activities and Their Impact on Brand Value in Food Enterprises in Slovakia Based on Foreign Participation
}

\author{
Zdenka Kádeková ${ }^{1}\left(\mathbb{D}\right.$, Radovan Savov $^{2, *}$, Ingrida Košičiarová ${ }^{1, *(\mathbb{C})}$ and Katarina Valaskova ${ }^{3}$ (]) \\ 1 Faculty of Economics and Management, Department of Marketing and Trade, Slovak University of \\ Agriculture in Nitra, Tr. A. Hlinku 2, 94976 Nitra, Slovakia; zdenka.kadekova@uniag.sk \\ 2 Faculty of Economics and Management, Department of Management, Slovak University of Agriculture in \\ Nitra, Tr. A. Hlinku 2, 94976 Nitra, Slovakia \\ 3 Faculty of Operation and Economics of Transport and Communications, University of Zilina, \\ 01026 Zilina, Slovakia; katarina.valaskova@fpedas.uniza.sk \\ * Correspondence: radovan.savov@uniag.sk (R.S.); ingrida.kosiciarova@gmail.com (I.K.); \\ Tel.: +421-37-641-4171 (I.K.)
}

Received: 15 May 2020; Accepted: 6 June 2020; Published: 14 June 2020

\begin{abstract}
This paper highlights the activity of corporate social responsibility (CSR) and its impact on brand value in food enterprises with and without foreign participation in Slovakia. Attention has been paid to all three pillars-People, Planet, Profit—and their communication in relation to customers, business partners, employees, local communities, environmental protection, and company values. The paper evaluates the impact of these activities on brand value in food enterprises in Slovakia. One hundred and twenty-five food enterprises were included in the research. The paper offers eight statistically tested hypotheses, of which three have been fully confirmed. Almost $86 \%$ of food companies with foreign participation apply CSR activities, while companies without foreign participation comprise only $40 \%$ of the total share. The biggest differences in the perception of the importance of CSR activities are noticeable in foundations and charitable activities, and in sponsorship and donations, but are less noticeable in terms of ecology, corporate transparency, and cooperation with non-profit organizations. In the field of environmental protection, CSR activities are communicated and used in order to build brand value, mostly in food enterprises with foreign participation. Almost $96 \%$ of food enterprises with foreign participation that apply and communicate CSR activities see an increase in their brand value.
\end{abstract}

Keywords: corporate social responsibility; brand value; communication; food enterprises

\section{Introduction}

In the 1970s, Reference [1] claimed that: "the only social responsibility of a company is the use of its resources together with the engagement in businesses that are meant to increase profits, maintaining the rules of the game. This means to engage in an open and free competition, without any abuse or fraud". This is how, since the 1970s, the "rules of the game" have been known in business, along with responsibility that triggers the community; a responsibility that companies fully acknowledge and embrace. Corporate social responsibility (CSR) deals with the strategies used by companies to develop their business in an ethical way and to respect their relationships with other members of society [2].

CSR is a modern concept that captures the trends of business, is focused on long-term goals, and penetrates into all areas of the company's business. The nature of the company's behavior towards the environment can have a significant impact on its position, brand value, and financial results [3]. 
However, large differences still remain in the literature regarding the CSR concept between economic and social approaches. In general, the economic approach is considered a voluntary business action that is inherently unprofitable. The social approach, on the other hand, either contributes to social benefits or responds in some way to stakeholder expectations [4].

To be successful, companies need long-term orientation to meet their objectives in the future. Sustainability is a megatrend in business [5] and higher education [6,7]. Long-term orientation encourages business relationships that last over time, and ethics play a key role in their formation [8]. Forty-one percent of the senior executives in a global survey by [9] confirmed that the desire to enhance reputation was the main driver behind sustainability efforts. Superior sustainability performance has a positive association with sustainability reputation [10]. To achieve sustainability, companies try to implement CSR actions that reflect their business ethics [11]. On the other hand, Reference [12] demonstrates that sustainability is an antecedent of CSR and should become a tool that can be used by stakeholders to enhance a company's activities. There is a requirement to include both sustainability and CSR in the strategic principles of the organization, which are implemented in the corporate strategy. There are many authors who link CSR and sustainability together and present them as synonyms $[13,14]$, and sometimes they use a new term-corporate sustainability [15]. Usually, sustainability includes economic, environmental, and social areas [16], and it is therefore highly connected with CSR. To achieve such a level of business ethics, companies often turn to CSR efforts [17]. Corporate social responsibility (CSR) is increasingly becoming a popular business concept in developed economies [18]. Business ethics and CSR are usually defined as concepts that are "doing good" [19]. Adoption of the CSR concept can bring many benefits to an organization. It should enhance the reputation of the company and decrease the risk [20]. Research by [12] also confirms other benefits, such as protection against difficulties, maximizing business survival, and brand value creation. Common values integrated into the CSR concept should decrease the level of conflict between managers, stakeholders, and employees [21]. Therefore, it supports the effectiveness of operations running in the company. Companies with strong CSR can achieve a competitive advantage, resulting in increased business revenue [22]. Nowadays, CSR is linked to the most important strategic factors of competitiveness.

As is evident from different studies and research, the issue of corporate social responsibility is a well-touted term in management disciplines. The mutual relationship between CSR and brand value is a highly discussed issue among researchers and academics worldwide, especially in developed countries. The situation is a bit different in emerging countries, including Slovakia, where research on the impact of CSR activities on brand values and consumer awareness is only in its early stages. The identified research gap opens up various opportunities for investigation. Corporate social responsibility plays a highly important role in the food industry [23] because this sector has a strong impact and a high dependence on the economy, the environment, and society. Thus, the purpose of this pioneering research is to reveal the reciprocal relationship between CSR activities and brand value in food enterprises with and without foreign participation in Slovakia. Recognition of the importance of CSR activities may help food enterprises increase both their competitive position and their sustainable development.

The presented paper is divided into four main sections. The Literature Review highlights the most important and most relevant studies and research published in the field of CSR activity and brand value. The Materials and Methods section presents the dataset of analyzed enterprises along with the hypotheses and methodological steps. The Results and Discussion section unveils the crucial findings and results of the testing of the hypotheses, comparing the outputs with other relevant studies. The Conclusions underline the main outcomes and present the limitations and future focus of the research.

\section{Literature Review}

Reference [24] stated that corporate social responsibility had become an integral part of corporate strategy. CSR initiatives are believed to not only benefit the local community, society, and the environment, but also help in the development of loyal consumers who are willing to pay a premium price for 
CSR-differentiated product or brands [25]. According to [26], corporate reputation for ethical behavior, which incorporates its integrity in dealing with stakeholders, is a part of brand value. Consumers' perception of corporate CSR activities can, therefore, have a positive effect on brand value. The empirical results of [27] indicate that CSR activities have a positive impact on brand performance [28].

Basic parts of CSR, such as the commitment to society, the environment, and transparency, are important strategic factors of competitiveness and management excellence [15]. Many times, authors have analyzed the influence of CSR on financial performance. There are two main viewpoints of this question. The first one sees CSR as a practice that entails costs that can worsen the financial performance of the company [29], and the costs explain the problems in implementing the CSR concept $[30,31]$. The numerous costs often outweigh the economic benefits and reduce profit [32]. Another problem is the agency cost theory, which indicates benefits for managers from the company's philanthropy [33], but stakeholders lose on these activities [34,35]. Reference [36] argues that the relationship between CSR and company performance is negative because of the potential inefficiencies caused by holding idle resources and self-serving managerial behavior. The second view shows the positive impact of CSR on business performance because companies have strong relationships with customers, competitors, public, and government. These connections can reduce social costs and increase market opportunities, leading to better performance [37]. According to [22], companies with better CSR ratings generate higher returns compared to those with low rating levels. They see the CSR as the investment in the best corporate citizens, which results in the superior market performance [38]. CSR and business performance are also tightly connected in the opposite way. Companies with good business results have more money to invest in CSR activities; thus, a company's performance has a positive effect on providing the CSR concept $[32,39]$ because they have more free resources to be used in community relations and environmental or philanthropic activities. Availability of free financial resources increases the level of the CSR engagement. On the other hand, a higher CSR level may lead to better business performance, and CSR should be viewed as an intangible asset of the company [40].

However, corporate social responsibility is strongly linked to the brand value.

The inclusion of CSR actions in a corporate strategy and its impact on brand value has become widespread both in research and practice [41,42]. As stated by [43], CSR helps build strategic competitive advantage and sustainable development of enterprises. Their research quantifies the impact of CSR on purchase intention, directly or indirectly, and they found out that customers perceive CSR unconsciously, but include the brand in the consideration as a consequence of positive manners trailing behind. The research of [44] reveals the factors that influence the reactions of customers to different CSR initiatives. Using a sample of 164 respondents, they proved that external CSR initiatives increase consumer willingness to purchase the products offered by an enterprise. The impact of CSR on corporate branding is explained comprehensively in the study of [45]. They affirm that economic, legal, ethical, and philanthropic elements of CSR have a significant impact on corporate branding and improve the loyalty of customers if CSR is an integral part of the corporate brand. These results are confirmed by [46], who report that CSR has a positive effect on brand image, consumer awareness, and brand loyalty. Integrating CSR into brand strategies is an important issue. As stressed by [47], CSR is an issue of large, usually international companies; however, there are hardly any studies focusing on small- and medium-sized enterprises. Their study investigates that the importance of CSR is slightly outweighed by product design and quality. An empirical survey of 315 students by [48] declares that a higher level of CSR activities has a positive effect on brand attitude. The findings of [49] using 386 empirical samples portray the importance of CSR when forming corporate social identity and consumer engagement for the brand. The latest research of [50] extends the existing research on CSR-related information to brand value, which has so far assumed the asymmetric impact of negative information on consumer attitudes and awareness to be predominant. Moreover, Reference [51] investigated sustainable brand management and verified the importance of internal and external factors related to corporate social responsibility that motivate customers to a positive relationship with a specific corporate brand. 
CSR is nowadays an important part of each modern company. Corporations pay significant attention to CSR activities on websites, social media, and annual reports. It was transformed into a marketing strategy and corporate strategic goal [52]. The codes of conduct, corporate culture, anti-pressure group campaigns, personnel training, and value reorientation are mentioned as the most highlighted actions that can increase the brand value of the company [18].

A higher perceived value of a brand product would drive a consumer to choose the brand rather than other competing products. Therefore, the degree to which the brand value is perceived by consumers reflects their willingness to pay a premium, and brand equity may increase [53].

Sustainability in the food production sector has become one of the most discussed topics of sustainable development in the global context [54]. We consider the CSR concept as the main driver of brand value that can help reach better sustainability, which was also the main reason for our research. The submitted paper assesses the relationship between sustainability and CSR in the food production sector.

\section{Materials and Methods}

This paper aims to point at CSR activities and their impact on the brand value in food enterprises with foreign participation and without foreign participation (Slovak food enterprises) in Slovakia. We focused on all three pillars of CSR-People, Planet, Profit—which were logically placed in the area of using CSR activities and their communication in relation to customers, business partners, employees, local community, environmental protection, and company values. The paper evaluates the impact of these activities on the brand value in the food enterprises in Slovakia.

The reason for choosing this object of research was our professional interest in this area, both in pedagogical and research terms, as well as in practice. We have been conducting research in the field of agriculture and food since 2009. The authors of the submitted paper work as the experts in the commission for the evaluation of the national projects of the Slovak Chamber of Agriculture and Food and, at the same time, as experts in the international project "Assessing and Changing Adults' Behavior on Sustainable Consumption of Food". The personal interviews with managers of food companies revealed a gap that needed to be explored. This gap was connected with CSR activities and their communication in order to build brand value.

The results of research and actual operation in the field of food led us to determine the object of the research of the submitted paper, which is the food sector of Slovakia, due to our professional background. It allowed us to conduct extensive research in food enterprises based on foreign participation in the territory of the Slovak Republic. The questionnaire research was conducted within 358 food enterprises listed in the Business Register of the Slovak Republic; 230 of them received the questionnaire in an electronic form.

The actual research was implemented in 125 food enterprises (Table 1).

Table 1. Representation of enterprises involved in the research by production focus.

\begin{tabular}{cc}
\hline Production Focus & Number of Enterprises \\
\hline Meat and meat processing enterprises & 29 \\
Enterprises processing milk and dairy products & 25 \\
Pastry and flour manufacturers & 22 \\
Enterprises producing alcoholic beverages & 15 \\
Enterprises producing vegetables & 14 \\
Enterprises whose main activity is processing of confectionery & 11 \\
Enterprises producing soft drinks & 9 \\
\hline Total & 125 \\
\hline Source: Own research.
\end{tabular}

A total of $57.6 \%$ of the analyzed subjects were food enterprises without foreign participation, and $42.4 \%$ of food enterprises were with foreign participation. 
The representativeness of the sample number of food enterprises was tested by $\chi^{2}$ test of good agreement (Table 2).

Table 2. $\chi^{2}$ test of good agreement-representativeness of sample-number of food enterprises.

\begin{tabular}{cc}
\hline Number of Food Enterprises & $\mathbf{3 5 8}$ \\
\hline Result of the test \\
\hline Calculated value & 16.05909 \\
Table value & 16.81298 \\
\hline Source: SOSR, authors' calculations, output XLSTAT.
\end{tabular}

When formulating the hypotheses, we relied on previous knowledge from our research activities [54-56] as well as from the research of acknowledged authors in the field of CSR [57-66].

As mentioned previously, there is a gap in the research regarding CSR and its impact on the brand value in food enterprises.

In the current business environment, the competition is very strong, and business success is dependent not only on the quality of the product and service offered by the company, but also on the relationship with various stakeholders, whose role in the successful operation of an enterprise is crucial. Therefore, it is important to use CSR activities to be successful enough to build a strong, positive image and reputation that can lead to a higher brand value. For long-term success, every company needs to have loyal customers, who do not shift to the competition even if it offers better prices. Nowadays, companies are facing increasing pressure to maintain profitability and, at the same time, to behave in socially and environmentally responsible ways. The shift of businesses' approach from profit orientation towards ethical, social, and environmental issues is a consequence of the shift of consumers' attitudes towards these issues [67].

The link between the concept of CSR and performance, as well as the impact of CSR on the competitiveness and brand value, is supported by various researches. Empirical studies provide data on the existence of a significant relationship between the competitive advantage, brand value, and performance of companies, especially in companies with foreign participation [68].

The quality of the CSR concept depends on the selection and method of combining its individual areas (economic, social, environmental). For companies, social responsibility is much more than just a price and charitable deeds - it can also be a source of opportunities, innovation, and competitive advantage. It is noteworthy that companies use this concept and its communication differently based on foreign participation [69].

Various entrepreneurs choose different approaches to improve their image, to attract customers, and to increase their brand value. The significance of corporate social responsibility is rising on a global scale and is seen as a key factor in the establishment of an attractive corporate image, building reputation, and providing a competitive advantage for the companies. The reason is the interaction with customers, which has changed dramatically over the past few years. Some studies emphasize that there is a positive relationship between the company's CSR actions, the customer behavior regarding those companies, and the brand value. However, there is no difference in the attitude of companies with or without foreign participation [70].

To answer the question of whether the activities within the CSR concept contribute more to brand value in food companies with foreign participation or food companies without foreign participation, eight hypothesis were set (see the Results section).

When evaluating the data and hypotheses, we used the frequency and contingency tables, the absolute and relative frequencies, $\chi^{2}$ test of good agreement, Likert scale, two-sample KolmogorovSmirnov $Z$ test, Pearson Chi-square test, exact tests, and the contingency coefficient $C$. When evaluating the hypotheses, non-parametric statistical testing was used due to the need to analyze the dependencies or differences with respect to the company's foreign participation. Monte Carlo simulation was used for testing. 
Based on a comparison of the calculated values and test criteria, we do not reject the null hypothesis; the sample number of food enterprises is representative on the significance level alpha 0.01 .

The software IBM SPSS Statistics version 25 was used to process the statistical data.

\section{Research Results}

\subsection{CSR Activities in Food Enterprises}

Hypothesis 1 (H1). The food enterprises with foreign participation use CSR activities more frequently than the food enterprises without foreign participation (Slovak food enterprises).

The frequency of application of CSR activities in the analyzed food companies, classified based on foreign participation, proved that up to $64.29 \%$ of food enterprises with foreign participation apply CSR activities in all three areas: People, Planet, Profit. In the food enterprises without foreign participation, this share is significantly lower: $24.74 \%$. More than $18 \%$ of food enterprises without foreign participation do not apply CSR now and do not plan to apply CSR activities in the future, while in the case of food enterprises with foreign participation, it is only $3.57 \%$.

Table 3 shows the results of Pearson's Chi-square test-we reject the null hypothesis of independence between the application of CSR and foreign participation. This is based on the fact that the asymptotic significance value of the Pearson's Chi-square test and the significance value estimated from Monte Carlo are less than the determined alpha significance level of 0.01 . The analyzed sample of food enterprises, divided according to foreign activity, applies the CSR policy in different ways. The perception of the importance of CSR activities for companies divided into groups according to foreign participation was analyzed using the nonparametric Kolmogorov-Smirnov Z test (Table 4). The biggest negative differences in distribution functions were found in all areas of CSR, which indicates that companies with foreign participation give more importance to specific CSR activities than companies without foreign participation. The biggest differences in the perception of the importance of CSR activities are in the foundation activities, charitable activities, sponsorship, and donations, and the lowest were in ecology, corporate transparency, and cooperation with non-profit organizations. Statistically significant differences in the perception of importance were found only in the case of foundation activities.

Table 3. Results of Pearson's Chi-square test of application of corporate social responsibility (CSR) activities based on foreign participation.

\begin{tabular}{|c|c|c|c|c|c|c|c|c|}
\hline \multicolumn{9}{|c|}{ Chi-Square Tests } \\
\hline & \multirow{3}{*}{ Value } & \multirow{3}{*}{ df } & \multirow{3}{*}{\multicolumn{2}{|c|}{$\begin{array}{c}\text { Asymptotic } \\
\text { Significance } \\
\text { (2-Sided) }\end{array}$}} & \multicolumn{4}{|c|}{ Monte Carlo Sig. (2-Sided) } \\
\hline & & & & & \multirow{2}{*}{\multicolumn{2}{|c|}{ Significance }} & \multicolumn{2}{|c|}{ 99\% Confidence Interval } \\
\hline & & & & & & & Lower Bound & Upper Bound \\
\hline Pearson Chi-Square & $19.666^{\mathrm{a}}$ & 3 & \multicolumn{2}{|c|}{0.000} & & 0.000 & 0.000 & 0.000 \\
\hline Likelihood Ratio & 20.893 & 3 & \multicolumn{2}{|c|}{0.000} & & 0.000 & 0.000 & 0.000 \\
\hline Linear-by-Linear Association & $18.116^{\mathrm{b}}$ & 1 & \multicolumn{2}{|c|}{0.000} & & 0.000 & 0.000 & 0.000 \\
\hline \multicolumn{9}{|c|}{$\begin{array}{l}\text { a Two cells }(25.0 \%) \text { have an expected count of less than } 5 \text {. The minimum expected count is } 4.26 .{ }^{b} \text { The standardized } \\
\text { statistic is }-4.256 \text {. Source: Authors' research and calculations, output IBM SPSS Statistics. }\end{array}$} \\
\hline \multicolumn{9}{|c|}{ Test Statistics $^{\text {a }}$} \\
\hline & & \multicolumn{5}{|c|}{ Most Extreme Differences } & \multirow{2}{*}{$\begin{array}{l}\text { Kolmogorov- } \\
\text { Smirnov Z }\end{array}$} & \multirow{2}{*}{$\begin{array}{l}\text { Asymp. Sig. } \\
\text { (2-Tailed) }\end{array}$} \\
\hline & & \multicolumn{2}{|c|}{ Absolute } & \multicolumn{2}{|c|}{ Positive } & Negative & & \\
\hline Foundation activities & & \multicolumn{2}{|c|}{0.414} & \multicolumn{2}{|c|}{0.010} & -0.414 & 1.521 & 0.020 \\
\hline Charitable activities & & \multicolumn{2}{|c|}{0.315} & \multicolumn{2}{|c|}{0.000} & -0.315 & 1.157 & 0.138 \\
\hline
\end{tabular}


Table 4. Cont.

\begin{tabular}{|c|c|c|c|c|c|}
\hline \multicolumn{6}{|c|}{ Test Statistics $^{\text {a }}$} \\
\hline & \multicolumn{3}{|c|}{ Most Extreme Differences } & \multirow{2}{*}{$\begin{array}{l}\text { Kolmogorov- } \\
\text { Smirnov Z }\end{array}$} & \multirow{2}{*}{$\begin{array}{l}\text { Asymp. Sig. } \\
\text { (2-Tailed) }\end{array}$} \\
\hline & Absolute & Positive & Negative & & \\
\hline Sponsorship & 0.266 & 0.033 & -0.266 & 0.977 & 0.295 \\
\hline Donations & 0.218 & 0.000 & -0.218 & 0.802 & 0.541 \\
\hline Cooperation with schools & 0.208 & 0.053 & -0.207 & 0.765 & 0.602 \\
\hline Employee care & 0.197 & 0.018 & -0.197 & 0.724 & 0.972 \\
\hline Equal job opportunities & 0.193 & 0.020 & -0.193 & 0.710 & 0.695 \\
\hline Employee training & 0.175 & 0.034 & -0.175 & 0.645 & 0.799 \\
\hline $\begin{array}{l}\text { Relations with state administration and } \\
\text { self-government institutions }\end{array}$ & 0.135 & 0.005 & -0.135 & 0.498 & 0.965 \\
\hline Relations with business partners & 0.104 & 0.083 & -0.104 & 0.383 & 0.999 \\
\hline Other & 0.086 & 0.000 & -0.086 & 0.318 & 1.000 \\
\hline Ecology & 0.083 & 0.000 & -0.083 & 0.304 & 1.000 \\
\hline Corporate transparency & 0.079 & 0.039 & -0.079 & 0.290 & 1.000 \\
\hline Cooperation with non-profit organizations & 0.044 & 0.015 & -0.044 & 0.161 & 1.000 \\
\hline
\end{tabular}

\subsection{CSR Activities Regarding the Customers}

Hypothesis 2 (H2). In the food enterprises with foreign participation as well as in the food enterprises without foreign participation (Slovak food enterprises), the CSR activities regarding the customers are understood and communicated in order to build the brand value on the same level.

For up to $80 \%$ of food enterprises with foreign participation, CSR activities regarding the customers are understood and communicated in order to build brand value as a matter of course. In the case of enterprises without foreign participation, this share is only slightly over $40 \%$. One-third of companies without foreign participation use only some CSR activities related to customers that are understood and communicated in order to build brand value. In the case of enterprises with foreign participation, this represents less than $17 \%$. A total of $21.43 \%$ of food enterprises without foreign participation mostly do not use CSR activities in relation to customers, and only $4.76 \%$ of food enterprises do not use these activities at all.

Table 5 shows the results of the use of CSR activities in relation to the customers of food enterprises in Slovakia based on foreign participation. The table is sorted according to the total percentage of evaluated options. The most frequently mentioned were options such as achieving certain quality standards, measuring customer satisfaction, organizing panel discussions, open days or testing new products by customers, and the existence of a loyalty program. The least indicated options were: Implementation of activities in the field of customer education and the implementation of other CSR activities. Food enterprises with foreign participation paid more attention to CSR activities such as organizing panel discussions, open days or testing new products by customers, and implementation of activities in the field of customer education, compared to the food enterprises without foreign participation.

Based on the results from Table 6, we can confirm the dependence between CSR activities regarding the customers that are understood and communicated in order to build the brand value in food enterprises with foreign participation. 
Table 5. CSR activities regarding the customers based on foreign participation.

\begin{tabular}{lcc}
\hline \multicolumn{1}{c}{ Activities Regarding the Customers } & \multicolumn{2}{c}{ Foreign Participation } \\
\cline { 2 - 3 } & No & Yes \\
\hline Achieving certain quality standards & $30.6 \%$ & $27.3 \%$ \\
\hline Measuring customer satisfaction & $24.0 \%$ & $22.7 \%$ \\
\hline $\begin{array}{l}\text { Organizing panel discussions, open days, or testing of new } \\
\text { products by customers }\end{array}$ & $16.5 \%$ & $19.3 \%$ \\
\hline Loyalty program & $17.4 \%$ & $14.8 \%$ \\
\hline Implementation of activities in the field of customer education & $9.1 \%$ & $12.5 \%$ \\
\hline Implementation of other CSR activities & $2.5 \%$ & $3.4 \%$ \\
\hline Total & $100.0 \%$ & $100.0 \%$ \\
\hline \multicolumn{2}{c}{ Source: Authors' research and calculations, output IBM SPSS Statistics. } \\
\end{tabular}

Table 6. Results of Pearson's Chi-square test of CSR activities regarding the customers that are understood and communicated in order to build brand value in food enterprises with foreign participation.

\begin{tabular}{ccccccc}
\hline & \multicolumn{3}{c}{ Chi-Square Tests } \\
& Value & df \begin{tabular}{c} 
Asymptotic \\
Significance \\
\cline { 5 - 7 }
\end{tabular} & & (2-Sided) & Significance & \multicolumn{2}{c}{ Monte Carlo Sig. (2-Sided) } \\
\cline { 5 - 7 } & $9.893^{\mathrm{a}}$ & 3 & 0.019 & 0.015 & Lower Bound & Upper Bound \\
\hline Pearson Chi-Square & 11.157 & 3 & 0.011 & 0.015 & 0.012 & 0.018 \\
\hline Likelihood Ratio & $9.120^{\mathrm{b}}$ & 1 & 0.003 & 0.004 & 0.003 & 0.006 \\
\hline Linear-by-Linear Association
\end{tabular}

${ }^{a}$ Three cells (37.5\%) have an expected count of less than 5 . The minimum expected count is $73{ }^{\mathrm{b}}$ The standardized statistic is 3.020. Source: Authors' research and calculations, output IBM SPSS Statistics.

\subsection{CSR Activities Regarding the Business Partners}

Hypothesis 3 (H3). In the food enterprises with foreign participation as well as in the food enterprises without foreign participation (Slovak food enterprises), the CSR activities regarding the business partners are understood and communicated in order to build the brand value on the same level.

The most common CSR activities in relation to business partners were identified in the analyzed group of enterprises: Providing clear and accurate information about products and services, interest in the origin of raw materials or goods purchased from business partners, and recording and resolving complaints from customers, suppliers, and business partners. Food enterprises without foreign participation focused more on providing clear and accurate information on products and services, recording and resolving complaints from customers and suppliers and business partners, and timely payment of supplier invoices compared to companies with foreign participation (Table 7).

More than $41 \%$ of food enterprises with foreign participation stated that it is a matter of course to implement CSR activities that are understood and communicated in relation to business partners in order to build the brand value. In the case of food enterprises without foreign participation, this share was lower, slightly more than $28 \%$. One-third of food enterprises with foreign participation use only some CSR activities in relation to customers, understood and communicated in order to build the brand value. Half of enterprises without foreign participation state that they mostly do not implement CSR activities in relation to business partners in order to build the brand value. In the case of enterprises with foreign participation, this percentage was significantly lower, only $25 \%$. More than $7 \%$ of enterprises without foreign participation claim that they do not use these activities at all. 
Table 7. CSR activities regarding the business partners based on foreign participation.

\begin{tabular}{|c|c|c|}
\hline \multirow{2}{*}{ Activities Regarding the Business Partners } & \multicolumn{2}{|c|}{ Foreign Participation } \\
\hline & No & Yes \\
\hline Providing clear, accurate information about products and services & $19.0 \%$ & $15.2 \%$ \\
\hline Interest in the origin of raw materials or goods purchased from business partners & $16.5 \%$ & $15.9 \%$ \\
\hline $\begin{array}{l}\text { Recording and resolving complaints from customers, suppliers, } \\
\text { and business partners }\end{array}$ & $17.0 \%$ & $12.3 \%$ \\
\hline Effective feedback, consultation, or dialogue with customers and suppliers & $14.0 \%$ & $11.6 \%$ \\
\hline Ensuring the timely payment of supplier invoices & $14.0 \%$ & $10.1 \%$ \\
\hline $\begin{array}{l}\text { Policy ensuring the honesty and quality of all contracts, negotiations, } \\
\text { and promotion (honest purchasing policy, consumer protection, etc.) }\end{array}$ & $7.5 \%$ & $10.9 \%$ \\
\hline Applying social or environmental criteria when choosing business partners & $6.0 \%$ & $7.2 \%$ \\
\hline $\begin{array}{l}\text { Working with other enterprises or organizations to solve problems related to } \\
\text { socially responsible business }\end{array}$ & $3.0 \%$ & $6.5 \%$ \\
\hline Providing the business partners with a report on CSR activities for inspection & $1.5 \%$ & $3.6 \%$ \\
\hline Involvement of business partners in CSR activities & $1.0 \%$ & $4.3 \%$ \\
\hline Business partners submit a CSR report to the enterprise & $0.5 \%$ & $2.2 \%$ \\
\hline Implementation of other CSR activities & $0.0 \%$ & $0.0 \%$ \\
\hline Total & $100.0 \%$ & $100.0 \%$ \\
\hline
\end{tabular}

Source: Authors' research and calculations, output IBM SPSS Statistics.

Based on the results from Table 8, we cannot confirm the dependence between CSR activities in relation to business partners that are understood and communicated in order to build the brand value and foreign participation.

Table 8. Results of Pearson's Chi-square test of CSR activities regarding the business partners that are understood and communicated in order to build brand value in food enterprises and foreign participation.

\begin{tabular}{|c|c|c|c|c|c|c|}
\hline \multicolumn{7}{|c|}{ Chi-Square Tests } \\
\hline & \multirow{3}{*}{ Value } & \multirow{3}{*}{ df } & \multirow{3}{*}{$\begin{array}{c}\text { Asymptotic } \\
\text { Significance } \\
\text { (2-Sided) }\end{array}$} & \multicolumn{3}{|c|}{ Monte Carlo Sig. (2-Sided) } \\
\hline & & & & \multirow{2}{*}{ Significance } & \multicolumn{2}{|c|}{ 99\% Confidence Interval } \\
\hline & & & & & Lower Bound & Upper Bound \\
\hline Pearson Chi-Square & $7.446^{\mathrm{a}}$ & 3 & 0.059 & 0.057 & 0.051 & 0.063 \\
\hline Likelihood Ratio & 8.482 & 3 & 0.037 & 0.050 & 0.045 & 0.056 \\
\hline Linear-by-Linear Association & $4.604^{\mathrm{b}}$ & 1 & 0.032 & 0.042 & 0.037 & 0.047 \\
\hline
\end{tabular}

\subsection{CSR Activities Regarding the Employees}

Hypothesis 4 (H4). In the food enterprises with foreign participation as well as in the food enterprises without foreign participation (Slovak food enterprises), the CSR activities regarding the employees are understood and communicated in order to build brand value on the same level.

The most frequently implemented CSR activities in relation to employees were the system for managing the area of health and safety at work, offering employees other benefits such as sports activities, more vacation days, and also supporting the dialogue with the employees in the form of comments, complaints, and mailboxes. Focusing on the mentioned activities, the food enterprises with foreign participation showed approximately the same values. For less than a third of food enterprises 
with foreign participation, the implementation of CSR activities in relation to employees is a matter of course that is understood and communicated in order to build the brand value. For food enterprises without foreign participation, this share is lower: $16.67 \%$. More than $41 \%$ of food enterprises with foreign participation apply only some of these CSR activities in relation to employees. More than $40 \%$ of food enterprises without foreign participation mostly do not carry out the mentioned activities. For food enterprises with foreign participation, these activities are usually not implemented by less than $30 \%$. Almost $12 \%$ of food enterprises without foreign participation do not apply CSR activities in relation to employees at all (Table 9).

Table 9. CSR activities regarding the employees based on foreign participation.

\begin{tabular}{|c|c|c|}
\hline \multirow{2}{*}{ Activities Regarding the Employees } & \multicolumn{2}{|c|}{ Foreign Participation } \\
\hline & No & Yes \\
\hline System for managing health and safety at work & $10.5 \%$ & $11.5 \%$ \\
\hline Offering employees other benefits (sport activities, more vacation days) & $11.2 \%$ & $10.5 \%$ \\
\hline $\begin{array}{l}\text { Supporting the dialogue with employees (boxes for suggestions, } \\
\text { comments, complaints) }\end{array}$ & $10.9 \%$ & $10.5 \%$ \\
\hline $\begin{array}{l}\text { Taking appropriate measures to ensure health, safety, and social care, which are a } \\
\text { guarantee of sufficient protection for employees }\end{array}$ & $10.5 \%$ & $9.4 \%$ \\
\hline Offering employees remuneration, performance wages, or profit shares & $9.8 \%$ & $7.9 \%$ \\
\hline Providing free training to employees & $8.1 \%$ & $7.3 \%$ \\
\hline $\begin{array}{l}\text { Encouraging employees to develop their skills and long-term career (e.g., through } \\
\text { a performance appraisal process, training plan) }\end{array}$ & $7.0 \%$ & $8.4 \%$ \\
\hline Pension system & $6.7 \%$ & $8.9 \%$ \\
\hline Spreading awareness of ethical issues among employees & $6.3 \%$ & $6.8 \%$ \\
\hline Consulting with employees on important matters & $4.9 \%$ & $3.1 \%$ \\
\hline $\begin{array}{l}\text { Supporting the reconciliation of work and private life (flexible working hours, } \\
\text { child care) }\end{array}$ & $4.2 \%$ & $3.7 \%$ \\
\hline $\begin{array}{l}\text { Process that ensures that adequate measures are taken against all forms of } \\
\text { discrimination, both in the workplace and during the recruitment of new } \\
\text { employees (e.g., women and men, ethnic groups, people with disabilities) }\end{array}$ & $2.8 \%$ & $4.7 \%$ \\
\hline $\begin{array}{l}\text { Offering the employees a suitable work-life balance, e.g., by allowing flexible } \\
\text { working hours or working from home }\end{array}$ & $3.5 \%$ & $2.6 \%$ \\
\hline $\begin{array}{l}\text { Corporate system that ensures the professional development of our employees } \\
\text { (career development plans) }\end{array}$ & $2.8 \%$ & $3.7 \%$ \\
\hline Employees know the ratio of internal promotions to external hiring & $0.4 \%$ & $0.5 \%$ \\
\hline Providing assistance to laid-off employees (help in finding a job, retraining) & $0.4 \%$ & $0.5 \%$ \\
\hline Total & $100.0 \%$ & $100.0 \%$ \\
\hline
\end{tabular}

Source: Authors' research and calculations, output IBM SPSS Statistics.

Based on the results from Table 10, it can be argued that food enterprises without foreign participation have a similar frequency of using the CSR activities in relation to employees that are understood and communicated in order to build the brand value compared to food enterprises with foreign participation. 
Table 10. Results of Pearson's Chi-square test of CSR activities regarding the employees that are understood and communicated in order to build brand value in food enterprises and foreign participation.

\begin{tabular}{|c|c|c|c|c|c|c|}
\hline \multicolumn{7}{|c|}{ Chi-Square Tests } \\
\hline & \multirow{3}{*}{ Value } & \multirow{3}{*}{ df } & \multirow{3}{*}{$\begin{array}{c}\text { Asymptotic } \\
\text { Significance } \\
\text { (2-Sided) }\end{array}$} & \multicolumn{3}{|c|}{ Monte Carlo Sig. (2-Sided) } \\
\hline & & & & \multirow{2}{*}{ Significance } & \multicolumn{2}{|c|}{ 99\% Confidence Interval } \\
\hline & & & & & Lower Bound & Upper Bound \\
\hline Pearson Chi-Square & $5.022^{a}$ & 3 & 0.170 & 0.179 & 0.169 & 0.189 \\
\hline Likelihood Ratio & 6.649 & 3 & 0.084 & 0.108 & 0.100 & 0.116 \\
\hline Linear-by-Linear Association & $4.334^{\mathrm{b}}$ & 1 & 0.037 & 0.044 & 0.038 & 0.049 \\
\hline
\end{tabular}

\subsection{CSR Activities Regarding the Support of the Local Community}

Hypothesis 5 (H5). In the food enterprises with foreign participation as well as in the food enterprises without foreign participation (Slovak food enterprises), the CSR activities regarding the support of the local community are understood and communicated in order to build the brand value on the same level.

Among the most frequently used CSR activities to support the local community (Table 11), the analyzed sample of food enterprises identified the following ones: Supporting events at the local, regional, and national levels, efforts to make purchases in the immediate area, and measuring the impact of business activities on society. Food enterprises without foreign participation apply more activities to support the local community by sponsoring events at the local, regional, and national levels, and they also try to make purchases in the immediate area to a greater extent than food enterprises with foreign participation. On the other hand, food enterprises with foreign participation have a more open dialogue about negative, controversial, or sensitive issues that affect the company compared to food enterprises without foreign participation. Cooperation with primary and secondary schools, colleges, or universities is more common in these food enterprises as well.

Table 11. CSR activities regarding the support of the local community based on foreign participation.

\begin{tabular}{lcc}
\hline \multicolumn{1}{c}{ Activities Regarding the Support of the Local Community } & Foreign Participation \\
\cline { 2 - 3 } & No & Yes \\
\hline Supporting events at the local, regional, and national levels & $21.1 \%$ & $16.7 \%$ \\
\hline Making purchases in the immediate area & $18.1 \%$ & $15.8 \%$ \\
\hline Measuring the impact of business activities on society & $15.7 \%$ & $17.5 \%$ \\
\hline $\begin{array}{l}\text { Providing financial support for public projects and activities (e.g., charitable } \\
\text { donations or sponsorships) }\end{array}$ & $13.9 \%$ & $14.2 \%$ \\
\hline $\begin{array}{l}\text { Having an open dialogue with the local community about negative, controversial, } \\
\text { or sensitive issues that affect the business }\end{array}$ & $10.2 \%$ & $14.2 \%$ \\
\hline Cooperating with primary schools, secondary schools, colleges, or universities & $5.4 \%$ & $9.2 \%$ \\
\hline $\begin{array}{l}\text { Encouraging the employees to participate in public activities (e.g., by providing } \\
\text { time, expertise, or tools) }\end{array}$ & $6.0 \%$ & $3.3 \%$ \\
\hline $\begin{array}{l}\text { Providing training to people from the local community (providing staff, training } \\
\text { places, or work experience for members of the local community) }\end{array}$ & $4.2 \%$ & $3.3 \%$ \\
\hline $\begin{array}{l}\text { Employees are involved in decisions about the subject of community assistance } \\
\text { Rewarding the voluntary work of employees }\end{array}$ & $3.0 \%$ & $2.5 \%$ \\
\hline Total & $2.4 \%$ & $3.3 \%$ \\
\hline
\end{tabular}


For almost $80 \%$ of food enterprises with foreign participation, the implementation of CSR activities to support the local community is a matter of course. In the case of food enterprises without foreign participation, this is less than $62 \%$. Less than $20 \%$ of food enterprises without foreign participation apply only some of the activities. For enterprises with foreign participation, this share is lower, specifically at the level of $12.5 \%$. Less than $15 \%$ of food enterprises without foreign participation mostly do not use the mentioned activities at all. For enterprises with foreign participation, this share is at the level of $8.33 \%$.

Based on the results from Table 12, the frequency of implementation of the mentioned activities is approximately the same for both groups of food enterprises, divided according to their foreign participation.

Table 12. Results of Pearson's Chi-square test of CSR activities regarding the support of the local community that are understood and communicated in order to build brand value in food enterprises and foreign participation.

\begin{tabular}{ccccccc}
\hline \multicolumn{7}{c}{ Chi-Square Tests } \\
& Value & df \begin{tabular}{c} 
Asymptotic \\
\cline { 5 - 7 }
\end{tabular} & $\begin{array}{c}\text { Significance } \\
\text { (2-Sided) }\end{array}$ & Significance & \multicolumn{2}{c}{ Monte Carlo Sig. (2-Sided) } \\
\cline { 5 - 7 } & $2.650^{\mathrm{a}}$ & 3 & 0.449 & 0.460 & Lower Bound & Upper Bound \\
\hline Pearson Chi-Square & 3.345 & 3 & 0.341 & 0.447 & 0.473 \\
\hline Likelihood Ratio & $2.391^{\mathrm{b}}$ & 1 & 0.122 & 0.162 & 0.152 & 0.441 \\
\hline Linear-by-Linear Association & & & & & &
\end{tabular}

${ }^{a}$ Four cells (50.0\%) have an expected count of less than 5 . The minimum expected count is $0.73{ }^{b}$ The standardized statistic is -1.546 . SPSS Source: Authors' research and calculations, output IBM SPSS Statistics.

\subsection{CSR Activities in the Field of Environmental Protection}

Hypothesis 6 (H6). In the field of environmental protection, the CSR activities are communicated and used in order to build the brand value mostly in the food enterprises with foreign participation.

The most frequently implemented CSR activities in the field of environmental protection include recycling, the fact that, in production activities and providing services, the food enterprises take into account the impact on the environment, compliance with national and international standards, and efforts to reduce the impact of activities on the environment. Among the analyzed groups of food enterprises, the percentages for specific CSR activities in the field of environmental protection are approximately the same (Table 13).

Table 13. CSR activities in the field of environmental protection based on foreign participation.

\begin{tabular}{lcc}
\hline \multicolumn{1}{c}{ Activities in the Field of Environmental Protection } & \multicolumn{2}{c}{ Foreign Participation } \\
\cline { 2 - 3 } & No & Yes \\
\hline Recycling & $13.0 \%$ & $12.4 \%$ \\
\hline Taking into account the impact on the environment in production activities and services & $11.9 \%$ & $10.2 \%$ \\
\hline Compliance with national and international standards (ISO, EMAS) & $10.5 \%$ & $11.8 \%$ \\
\hline Reducing the impact of the company's activities on the environment & $10.5 \%$ & $10.8 \%$ \\
\hline Having an established program for control/overview of energy and water consumption & $9.8 \%$ & $9.1 \%$ \\
\hline $\begin{array}{l}\text { Providing the customers, suppliers, and the community with clear and accurate } \\
\text { environmental information about products, services, and activities }\end{array}$ & $10.5 \%$ & $8.1 \%$ \\
\hline Used materials can be reused or recycled & $7.4 \%$ & $9.7 \%$ \\
\hline Having a waste management policy & $6.7 \%$ & $7.5 \%$ \\
\hline
\end{tabular}


Table 13. Cont.

\begin{tabular}{lcc}
\hline \multirow{2}{*}{ Activities in the Field of Environmental Protection } & \multicolumn{2}{c}{ Foreign Participation } \\
\cline { 2 - 3 } & No & Yes \\
\hline Communicating the environmental policy with the employees and public & $6.7 \%$ & $7.0 \%$ \\
\hline Having an environmental management system & $6.7 \%$ & $6.5 \%$ \\
\hline Having a policy of reducing fuel consumption & $3.5 \%$ & $3.2 \%$ \\
\hline Providing the environmental training to employees & $2.8 \%$ & $3.8 \%$ \\
\hline Total & $100.0 \%$ & $100.0 \%$ \\
\hline
\end{tabular}

Source: Authors' research and calculations, output IBM SPSS Statistics.

Most of the food enterprises with foreign participation (91.67\%) consider the frequency of implementation of CSR activities in the field of environmental protection that is understood and communicated in order to build the brand value. In the case of enterprises without foreign participation, it is at the level of $76.19 \%$.

\subsection{CSR Activities Regarding the Company Values}

Hypothesis 7 (H7). In the food enterprises with foreign participation as well as in the food enterprises without foreign participation (Slovak food enterprises), the CSR activities regarding the company values are understood and communicated in order to build the brand value on the same level.

According to our research, the most frequently used CSR activities regarding the company values include activities such as the company's clearly defining company values and rules of conduct, communicating the values of the company with customers, business partners, suppliers, and other stakeholders, and employees' awareness of the values of the company and the rules of conduct. Food enterprises, divided based on foreign participation, do not show significant differences in the percentages of the analyzed CSR activities in relation to company values.

For most of the analyzed food companies with foreign participation, it is a matter of course to understand and communicate company values in order to build the brand value. For enterprises without foreign participation, this share is only $48.78 \%$. More than $39 \%$ of food enterprises without foreign participation implement only some CSR activities regarding the company values that are understood and communicated in order to build the brand value. More than $7 \%$ of food enterprises without foreign participation do not apply any CSR activities at all (Table 14).

Table 14. CSR activities regarding the company values based on foreign participation.

\begin{tabular}{lcc}
\hline \multicolumn{1}{c}{ Activities in Relation to the Brand Value } & Foreign Participation \\
\cline { 2 - 3 } & No & Yes \\
\hline Clearly defined company values and rules of conduct & $32.5 \%$ & $22.4 \%$ \\
\hline $\begin{array}{l}\text { Communicating the values of the company with customers, business partners, } \\
\text { suppliers, and other stakeholders (e.g., at sales presentations, informal meetings) }\end{array}$ & $23.0 \%$ & $20.6 \%$ \\
\hline Employees are aware of the values of the company and the rules of conduct & $15.1 \%$ & $16.8 \%$ \\
\hline $\begin{array}{l}\text { Training the employees with regard to the importance of company values and rules } \\
\text { of conduct }\end{array}$ & $11.9 \%$ & $10.3 \%$ \\
\hline $\begin{array}{l}\text { Community in which the company operates is aware of the values of our society and } \\
\text { the rules of conduct }\end{array}$ & $6.3 \%$ & $14.0 \%$ \\
\hline Business partners are aware of company values and the rules of conduct & $6.3 \%$ & $9.3 \%$ \\
\hline Customers are aware of company values and the rules of conduct & $4.8 \%$ & $6.5 \%$ \\
\hline Total & $100.0 \%$ & $100.0 \%$ \\
\hline
\end{tabular}

Source: Authors' research and calculations, output IBM SPSS Statistics. 
Based on the results presented in Table 15, we can say that the analyzed sample of food enterprises implements various CSR activities in relation to company values based on foreign participation.

Table 15. Results of Pearson's Chi-square test of CSR activities related to company values that are understood and communicated in order to build brand value in food enterprises and foreign participation.

\begin{tabular}{|c|c|c|c|c|c|c|}
\hline \multicolumn{7}{|c|}{ Chi-Square Tests } \\
\hline & \multirow{3}{*}{ Value } & \multirow{3}{*}{ df } & \multirow{3}{*}{$\begin{array}{l}\text { Asymptotic } \\
\text { Significance } \\
\text { (2-Sided) }\end{array}$} & \multicolumn{3}{|c|}{ Monte Carlo Sig. (2-Sided) } \\
\hline & & & & \multirow{2}{*}{ Significance } & \multicolumn{2}{|c|}{ 99\% Confidence Interval } \\
\hline & & & & & Lower Bound & Upper Bound \\
\hline Pearson Chi-Square & $15.600^{\mathrm{a}}$ & 3 & 0.001 & 0.000 & 0.000 & 0.001 \\
\hline Likelihood Ratio & 21.643 & 3 & 0.000 & 0.000 & 0.000 & 0.000 \\
\hline Linear-by-Linear Association & $8.935^{b}$ & 1 & 0.003 & 0.002 & 0.001 & 0.003 \\
\hline
\end{tabular}

\subsection{CSR Activities in Relation to the Brand Value}

Hypothesis 8 (H8). The food enterprises with foreign participation perceive the increase in brand value from using and communicating CSR activities more positively than the food enterprises without foreign participation (Slovak food enterprises).

As we can see in Table 16, the food enterprises with foreign participation perceive the increase of brand value from using and communicating CSR activities more positively than the food enterprises without foreign participation (Slovak food enterprises).

Table 16. Results of Pearson's Chi-square test-increase of brand value by using and communicating CSR activities and foreign participation.

\begin{tabular}{|c|c|c|c|c|c|}
\hline \multicolumn{6}{|c|}{ Chi-Square Tests } \\
\hline & Value & df & $\begin{array}{c}\text { Asymptotic } \\
\text { Significance (2-Sided) }\end{array}$ & $\begin{array}{l}\text { Exact Sig. } \\
\text { (2-Sided) }\end{array}$ & $\begin{array}{l}\text { Exact Sig. } \\
\text { (1-Sided) }\end{array}$ \\
\hline Pearson Chi-Square & $4.243^{\mathrm{a}}$ & 1 & 0.039 & \multirow{4}{*}{0.046} & \multirow{4}{*}{0.037} \\
\hline Likelihood Ratio & 2.946 & 1 & 0.086 & & \\
\hline Fisher's Exact Test & 5.055 & 1 & 0.025 & & \\
\hline Linear-by-Linear Association & $4.179^{b}$ & 1 & 0.041 & & \\
\hline
\end{tabular}

\section{Discussion}

The submitted paper pointed at the CSR concept as a strategic brand communication tool contributing to the brand value in the practice of food enterprises in Slovakia based on foreign participation. Questionnaire research was implemented in 125 food enterprises. To achieve this aim, eight hypotheses were set.

Hypothesis 1: According to our research, almost $86 \%$ of food companies in Slovakia with foreign participation apply CSR either in all three areas or in at least one of them. Only $40 \%$ of the analyzed food companies in Slovakia without foreign participation apply CSR either in all three areas or in at least one area. Food enterprises with foreign participation give more importance to specific areas of CSR than enterprises without foreign participation.

H1 was confirmed. 
Hypothesis 2: Regarding the customers, the food companies with foreign participation paid more attention to CSR activities, such as organizing panel discussions or open days or implementing activities in the field of customer education, compared to companies without foreign participation. Up to $97 \%$ of the analyzed food companies with foreign participation understand and communicate CSR activities regarding the customers in order to build the brand value. In the case of food enterprises without foreign participation, this share is only $73 \%$.

$\mathrm{H} 2$ was not confirmed.

Hypothesis 3: The analyzed group of food enterprises identified the following CSR activities regarding business partners as the most common ones: Providing clear, accurate information about products and services or interest in the origin of raw materials or goods purchased from business partners. The food enterprises without foreign participation focused more on providing clear and accurate information about products and services and recording and resolving complaints from customers, suppliers, and business partners. Almost $75 \%$ of companies with foreign participation stated that they understand and communicate CSR activities regarding the business partners in order to build the brand value, while in the case of food enterprises without foreign participation, it was only $43 \%$.

H3 was not confirmed.

Hypothesis 4: The most frequently implemented activities regarding the employees were the system for managing health and safety at work and offering employees other benefits, such as sports activities, more vacation days, etc. For almost $71 \%$ of the analyzed food enterprises with foreign participation, the implementation of CSR activities regarding the employees is understood and communicated in order to build the brand value. For food enterprises without foreign participation, this share is lower, only $47 \%$.

H4 was not confirmed.

Hypothesis 5: Among the most frequently used CSR activities to support the local community, the analyzed sample of food businesses marked "supporting the events at the local, regional, and national levels". Food enterprises without foreign participation try to make purchases in the immediate area to a greater extent than the food enterprises with foreign participation, and also cooperate with primary schools, secondary schools, colleges, or universities more often. Almost $92 \%$ of the analyzed food companies with foreign participation communicate their activities in the field of CSR in order to build the brand value; for the analyzed companies without foreign participation, this share is almost $81 \%$.

H5 was not confirmed.

Hypothesis 6: In the field of environmental protection, recycling was one of the most frequently used activities in the analyzed food enterprises, followed by "taking into account the impact on the environment in production activities and services". For most of the food enterprises with foreign participation (almost 96\%), it is a matter of course to understand and communicate CSR activities related to environmental protection in order to build the brand value. For food enterprises without foreign participation, this share is almost $88 \%$.

H6 was confirmed.

Hypothesis 7: The following activities were identified as the most frequently used CSR activities regarding the company values in the analyzed food enterprises: The company has clearly defined company values and rules of conduct, communicates the values of the company with customers, business partners, suppliers, and other stakeholders, and employees are aware of the values of the company and the rules of conduct. Food enterprises divided based on their foreign participation do not show significant differences in the percentages of the analyzed CSR activities in relation to company values.

For most of the analyzed food companies with foreign participation, it is a matter of course to understand and communicate company values in order to build the brand value. For enterprises without foreign participation, this share is only half. 
H7 was not confirmed.

Hypothesis 8: The results of the Pearson's Chi-square test aimed at increase of the brand value using CSR activities and their communication based on the foreign participation proved that the food enterprises with foreign participation perceive the increase of brand value from using and communicating CSR activities more positively than the food enterprises without foreign participation (Slovak food enterprises).

H8 was confirmed.

In his research, Reference [71] examined the presence of sectoral differences in using the basic dimensions of CSR and sustainability, as well as the role of CSR in influencing the brand value. Similar researches $[23,63,72-76]$ proved that the area of the company's social involvement and its communication with the public depends on the industry in which it operates. Businesses in the service sector appeal more to the dimensions of volunteering and economic and social responsibility. On the other hand, primary sector enterprises, such as agriculture, extractive industries, and industrial enterprises, are more oriented towards the environment and environmental responsibilities. Reference [71] also proved statistically insignificant differences between businesses, their CSR activities, sustainability, and their role in building brand value in different sectors of the national economy. He also confirmed that some sectors are more socially responsible than others.

Reference [28] conducted a study regarding corporate social responsibility and sustainability as sources of competitive advantage and value creation for the company, as this is a question that frequently comes into the minds of many managers, CEOs, and business leaders. To address this question, their study aimed to examine the effect of CSR initiatives and sustainability on the brand value. Looking back at the empirical research done in the past few years, the business case for responsibility towards society and the related link between corporate social performance (CSP) and corporate financial performance (CFP) has been the most controversial in the business and society area [77]. However, the study by [28] argues that CSR has a positive effect on the brand value, which, in turn, enhances the brand's performance.

Strong support for a positive relationship between CSR, sustainability, and company values was also recorded in the academic area [78]. According to prior research, CSR and sustainability can multiply the brand value and establish competitive advantages [77,79]. Many studies analyzed the impact of CSR activities on the value of enterprises that use long-term orientation and principles of sustainability $[37,38,52,80]$. CSR and sustainability strengths do affect the level of brand value in a positive way. The findings of [81] indicate that strategic CSR and sustainability enhance the brand value, while socially irresponsible activities that are against social norms, values, and ethics affect the companies' legitimacy and adversely affect changes in brand reputation. CSR actions can upgrade value in the minds of consumers and increase the brand value by enhancing its reputation on the market $[77,82]$. This leads to higher customer satisfaction and willingness to buy products [11], as they trust in the ethical values shared by the company. On the other hand, some researches indicate differences between brand value, CSR, and sustainability [15]. Some academicians try to solve this issue. Reference [83] focused on the fact that willingness to be engaged in CSR and sustainability influences customer loyalty and commitment to support and recommend the organization, which can help to enhance the brand value.

Since there are also some negative aspects of CSR on the brand value [20], we are more prone to agree with its positive influence. Nevertheless, we would like to add some predictions to this discussion to show how CSR really increases the brand value. First of all, CSR has to be among company's priorities and goals. Secondly, CSR can work only in companies where stakeholders, managers, and employees can share similar values. Moreover, a company needs to have free financial resources to invest in social activities. A company also needs strong marketing focused on CSR activities. Lastly, it requires a great deal of patience from managers and stakeholders while positive effects become visible because it is a gradual process; thus, a long-term orientation is necessary. 


\section{Conclusions}

Despite its complexity, we carried out a questionnaire survey in food enterprises in the Slovak Republic. It was a unique study that connected CSR activities and brand value in the conditions of food enterprises in Slovakia. Research with such a focus on food enterprises has not yet been carried out by any other researcher, either in Slovakia or worldwide. The results of a survey of 125 analyzed food enterprises based on foreign participation proved that, although the CSR concept is known to food enterprises, there are still many enterprises that do not actively apply and communicate CSR activities. There are also many cases where food enterprises act socially responsibly, but do not know how to professionally classify their actions under this concept. Food enterprises that apply CSR activities and communicate them in order to build the brand value feel that the public perceives them more positively, increasing the image of the company and their brand value. The concept of CSR and its communication with the public ultimately leads to an increase in the popularity of companies as well as an increase in sales of goods and services. The connection of the CSR activities with their impact on brand value represents a competitive advantage and strategy.

Especially in food enterprises, it is vital for all of us that they act based on the three dimensions of CSR, and that this action is an appeal to the community, customers, and other internal and external members of the public to place their trust in businesses and to choose products and services, or even employers.

The enterprises should inform about applying CSR activities and use this potential to build the company's reputation, increase the brand value, create a love mark, improve human capital, increase employee productivity by increasing their satisfaction and skills, reduce costs related to environmental practices, build more trustworthy relationships with the customers as well as suppliers, and, last but not least, the facilitate the conservation of natural resources for society as a whole. In today's really challenging time and competitive environment, the connection of CSR and brand value is becoming a highly topical and important task for companies in all areas not only in Slovakia, but also worldwide.

Based on the results of our research, it can be concluded that the application of activities of the CSR concept in the everyday lives of food enterprises with foreign participation in Slovakia is more perceptible, and these enterprises consider and communicate CSR activities as a strategic brand communication tool in order to build and increase the brand value more often than in the case of Slovak food enterprises without foreign participation.

However, our research also has some limitations. We focused on food enterprises just in the area of the Slovak Republic. We also realize the fact that CSR is evolving over time, and the situation described in the submitted paper may change in the near future. Another limitation of our research is the fact that our research was focused only on food enterprises based on their foreign participation. This is the point from which further possibilities and trends for future research arise. The solved issue might be examined from the perspective of production focus, legal form, and size of food enterprises, while enterprises from other sectors of the economy could be interesting subjects for research in this area as well, not only in Slovakia but also abroad. We are convinced that the submitted paper creates a solid basis for further research and practical application in the field of improving the functioning of the agri-food complex regarding CSR activities and their impact on the brand value of the enterprises in Slovakia and other Eastern and Central European countries. This could provide an answer concerning the low level of applying CSR activities in the enterprises without foreign participation, also from the managerial point of view.

Corporate social responsibility is becoming increasingly important, and it can be argued that it is also a key factor in the success of enterprises in Slovakia and abroad. Especially in food enterprises, it is necessary to pay very close attention to the origin of raw materials, ecology, product quality, and many other aspects that directly or indirectly affect the entire population, its health, and the safety of our everyday food. 
Author Contributions: Conceptualization, I.K., Z.K., and R.S.; methodology, I.K., Z.K., R.S., and K.V.; software, I.K., Z.K., and R.S.; validation, I.K., Z.K., and R.S.; formal analysis, I.K., Z.K., R.S., and K.V.; investigation, I.K., Z.K., R.S., and K.V.; resources, I.K., Z.K., R.S., and K.V.; data curation, I.K., Z.K., and R.S.; writing-original draft preparation, I.K., Z.K., and R.S.; writing-review and editing, I.K., Z.K., R.S., and K.V.; visualization, I.K., Z.K., and R.S.; supervision, I.K., Z.K., R.S., and K.V.; project administration, I.K. and Z.K.; funding acquisition, I.K., Z.K., R.S., and K.V. All authors have read and agreed to the published version of the manuscript.

Funding: This research received no external funding.

Conflicts of Interest: The authors declare no conflict of interest.

\section{References}

1. Friedman, M. The social responsibility of business is to increase its profits. The New York Times Magazine, 13 September 1970. [CrossRef]

2. Dinu, V.; Bunea, M. The Corporate Social Responsibility of the Romanian Banking System. EM Econ. Manag. 2019, 22, 119-133. [CrossRef]

3. Kunz, V. Společenská Odpovědnost Firem; Grada: Prague, Czech, 2012; 208p.

4. Windsor, D. Defining Corporate Social Responsibility for Developing and Developed Countries: Comparing Proposed Approaches. In Corporate Social Responsibility: Concepts, Methodologies, Tools, and Applications; Business Science Reference: Hershey, PA, USA, 2018; pp. 1-27.

5. Lubin, D.A.; Esty, D.C. The sustainability imperative. Harv. Bus. Rev. 2010, 88, 42-50.

6. Chebeň, J.; Lančarič, D.; Munk, M.; Obdržálek, P. Determinants of Economic Sustainability in Higher Education Institutions. Amfiteatru Econ. 2020, 22, 462-479. [CrossRef]

7. Dabija, D.C.; Dinu, V.; Abrudan, I.N.; Postelnicu, C. The Impact of the Marketing Mix and Sustainability on Shaping Consumer Preferences towards Non-Food Stores. Transform. Bus. Econ. 2014, 13, 36-53.

8. Monga, A.B.; John, D.R. Cultural differences in brand extension evaluation: The influence of analytic versus holistic thinking. J. Consum. Res. 2007, 33, 529-536. [CrossRef]

9. KPMG's. KPMG Annual Review 2011 Highlights Client Focus of Fastest-Growing of the Big Four. 2011. Available online: https:/home.kpmg/cn/en/home/news-media/press-releases/2012/01/kpmg-annual-review2011.html. (accessed on 5 May 2020).

10. Alon, A.; Vidovic, M. Sustainability performance and assurance: Influence on reputation. Corp. Reput. Rev. 2015, 18, 337-352. [CrossRef]

11. Ki, C.; Kim, Y.K. Sustainable Luxury Fashion Consumption and the Moderating Role of Guilt. Fash. Ind. Educ. 2016, 14, 18-30. [CrossRef]

12. Gomez-Trujillo, A.M.; Velez-Ocampo, J.; Gonzalez-Perez, M.A. A literature review on the causality between sustainability and corporate reputation: What goes first? Manag. Environ. Qual. 2020, 31, 406-430. [CrossRef]

13. Abreu, M.C.S.D.; Cunha, L.T.D.; Barlow, C.Y. Institutional dynamics and organizations affecting the adoption of sustainable development in the United Kingdom and Brazil. Bus. Ethics Eur. Rev. 2015, 24, 73-90. [CrossRef]

14. Choi, Y.; Yu, Y. The influence of perceived corporate sustainability practices on employees and organizational performance. Sustainability 2014, 6, 348-364. [CrossRef]

15. Alcaide, M.Á.; De La Poza, E.; Guadalajara, N. Assessing the Sustainability of High-Value Brands in the IT Sector. Sustainability 2019, 11, 1598. [CrossRef]

16. Liang, X.; Zhao, X.; Wang, M.; Li, Z. Small and medium-sized enterprises sustainable supply chain financing decision based on triple bottom line theory. Sustainability 2018, 10, 4242. [CrossRef]

17. Schwartz, M.S.; Carroll, A.B. Integrating and unifying competing and complementary frameworks: The search for a common core in the business and society field. Bus. Soc. 2008, 47, 148-186. [CrossRef]

18. Amaeshi, K.; Adegbite, E.; Ogbechie, C.; Idemudia, U.; Kan, K.A.S.; Issa, M.; Anakwue, O.I. Corporate social responsibility in SMEs: A shift from philanthropy to institutional works? J. Bus. Ethics 2016, 138, 385-400. [CrossRef]

19. Diallo, M.F.; Mouelhi, N.B.D.; Gadekar, M.; Schill, M. CSR Actions, Brand Value, and Willingness to Pay a Premium Price for Luxury Brands: Does Long-Term Orientation Matter? J. Bus. Ethics 2020, 3, 1-20. [CrossRef]

20. Servaes, H.; Tamayo, A. The impact of corporate social responsibility on firm value: The role of customer awareness. Manag. Sci. 2013, 59, 1045-1061. [CrossRef] 
21. Jo, H.; Harjoto, M.A. Corporate governance and firm value: The impact of corporate social responsibility. J. Bus. Ethics 2011, 103, 351-383. [CrossRef]

22. Statman, M.; Glushkov, D. The Wages of Social Responsibility. Financ. Anal. J. SSRN 2009, 65, 33-46. [CrossRef]

23. Hartmann, M. Corporate social responsibility in the food sector. Eur. Rev. Agric. Econ. 2011, 38, $297-324$. [CrossRef]

24. Singh, A.; Verma, P. From philanthropy to mandatory CSR: A journey towards mandatory corporate social responsibility in India. Eur. J. Bus. Manag. 2014, 6, 146-152.

25. McFadden, D.; Deselnicu, O.; Costanigro, M. How consumer respond to corporate social responsibility initiatives: A cluster analysis of dairy consumers. J. Food Distrib. Res. 2013, 44, 17-24.

26. Brickley, J.; Smith, C.; Zimmerman, J. Business ethics and organizational architecture. J. Bank. Financ. 2002, 26, 1821-1835. [CrossRef]

27. Lai, C.S.; Chiu, C.J.; Yang, C.F.; Pai, D.C. The effect of corporate social responsibility on brand performance: The mediating effect of industrial brand equity and corporate reputation. J. Bus. Ethics 2010, 95, 457-469. [CrossRef]

28. Singh, A.; Verma, P. Driving Brand Value through CSR Initiatives: An Empirical Study in Indian. Perspect. Glob. Bus. Rev. 2018, 19, 85-98. [CrossRef]

29. Friedman, M. Comment on Tobin. Q. J. Econ. 1970, 84, 318-327. [CrossRef]

30. Acquier, A.; Valiorgue, B.; Daudigeos, T. Sharing the shared value: A transaction cost perspective on strategic CSR policies in global value chains. J. Bus. Ethics 2017, 144, 139-152. [CrossRef]

31. Lund-Thomsen, P.; Lindgreen, A. Corporate social responsibility in global value chains: Where are we now and where are we going? J. Bus. Ethics 2014, 123, 11-22. [CrossRef]

32. Waddock, S.A.; Graves, S.B. The corporate social performance-financial performance link. Strateg. Manag. J. 1997, 18, 303-319. [CrossRef]

33. Barnea, A.; Rubin, A. Corporate social responsibility as a conflict between shareholders. J. Bus. Ethics 2010, 97, 71-86. [CrossRef]

34. Brown, W.O.; Helland, E.; Smith, J.K. Corporate philanthropic practices. J. Corp. Financ. 2006, $12,855-877$. [CrossRef]

35. Helland, E.; Smith, J.K. An Analysis of Corporate Philanthropic Practices. Working Paper. 2004. Available online: http://citeseerx.ist.psu.edu/viewdoc/download?doi=10.1.1.377.9386\&rep=rep1\&type=pdf (accessed on 30 May 2020).

36. Stan, C.V.; Peng, M.W.; Bruton, G.D. Slack and the performance of state-owned enterprises. Asia Pac. J. Manag. 2014, 31, 473-495. [CrossRef]

37. Kao, E.H.; Yeh, C.C.; Wang, L.H.; Fung, H.G. The relationship between CSR and performance: Evidence in China. Pac.-Basin Financ. J. 2018, 51, 155-170. [CrossRef]

38. Filbeck, G.; Gorman, R.; Zhao, X. The "Best Corporate Citizens": Are they good for their shareholders? Financ. Rev. 2009, 44, 239-262. [CrossRef]

39. Tan, J.; Peng, M.W. Organizational slack and firm performance during economic transitions: Two studies from an emerging economy. Strateg. Manag. J. 2003, 24, 1249-1263. [CrossRef]

40. Chiu, S.C.; Sharfman, M. Legitimacy, visibility, and the antecedents of corporate social performance: An investigation of the instrumental perspective. Jsoui J. Manag. 2011, 37, 1558-1585. [CrossRef]

41. Golob, U.; Podnar, K. Researching CSR and brands in the here and now: An integrative perspective. J. Brand Manag. 2019, 26, 1-8. [CrossRef]

42. Carlini, J.; Grace, D.; France, C.; Lo Iacono, J. The corporate social responsibility (CSR) employer brand process: Integrative review and comprehensive model. J. Mark. Manag. 2019, 35, 182-205. [CrossRef]

43. Ramesh., K.; Saha, R.; Goswami, S.; Dahiya, R. Consumer's response to CSR activities: Mediating role of brand image and brand attitude. Corp. Soc. Responsib. Environ. Manag. 2019, 26, 377-387. [CrossRef]

44. Amatulli, C.; De Angelis, M.; Korschun, D.; Romani, S. Consumers' perception of luxury brands' CSR initiatives: An investigation of the role of status and conspicuous consumption. J. Clean. Prod. 2018, 194, 277-287. [CrossRef]

45. Pratihari, S.K.; Uzma, S.H. CSR and corporate branding effect on brand loyalty: A study on Indian banking industry. J. Prod. Brand Manag. 2018, 27, 57-78. [CrossRef] 
46. Martinez, R.; Nishiyama, N. Enhancing customer-based brand equity through CSR in the hospitality sector. Int. J. Hosp. Tour. Adm. 2019, 20, 329-353. [CrossRef]

47. Ben Youssef, K.; Leicht, T.; Pellicelli, M.; Kitchen, P.J. The importance of corporate social responsibility (CSR) for branding and business success in small and medium-sized enterprises (SME) in a business-to-distributor (B2D) context. J. Strateg. Mark. 2018, 26, 723-739. [CrossRef]

48. Kim, S.; Lee, H. The effect of CSR fit and CSR authenticity on the brand attitude. Sustainability 2020, $12,275$. [CrossRef]

49. Bhattacharya, S. Does corporate social responsibility contribute to strengthen brand equity? An empirical study. Int. Rev. Public Nonprofit Mark. 2017, 14, 513-533. [CrossRef]

50. Brunk, K.H.; de Boer, C. How do conusmers reconcile positive and negative CSR-related information to form and ethical brand perception? A mixed method inquiry. J. Bus. Ethics 2020, 161, 443-458. [CrossRef]

51. Majerova, J.; Sroka, W.; Krizanova, A.; Gajanova, L.; Lazaroiu, G.; Nadanyiova, M. Sustainable Brand Management of Alimentary Goods. Sustainability 2020, 12, 556. [CrossRef]

52. Ding, D.K.; Ferreira, C.; Wongchoti, U. Does it pay to be different? Relative CSR and its impact on firm value. Int. Rev. Financ. Anal. 2016, 47, 86-98. [CrossRef]

53. Kim, R. Determinants of brand equity for credence goods: Consumers' preference for country origin, perceived value and food safety. Agric. Econ. (Agricecon) 2012, 58, 299-307. [CrossRef]

54. Kádeková, Z. Spoločenská Marketingová Koncepcia a PR v Praxi Podnikov, 1st ed.; Verbum: Prahgue, Czech Republic, 2019; 177p.

55. Kádeková, Z.; Kubicová, L'.; Récky, R. Current practices and future development of strategic marketing communication in Europe. In Managerial Trends in the Development of Enterprises in Globalization ERA; Slovenská Pol'nohospodárska Univerzita: Nitra, Slovakia, 2017; pp. 784-789.

56. Kádeková, Z.; Košičiarová, I.; Holienčinová, M.; Kubicová, L'; Koprda, T. Event marketing as part of corporate social responsibility in the food enterprises in Slovakia. Analýza A Výskum V Mark. Komunikácii 2018, 6, 5-15.

57. Bulanda, I.; Viteková, I.; Koprda, T.; Blahová, B. Slovak Consumers from Generation Y and Their Shopping Behavior on Discount Portals. In International Scientific Days 2018: Towards Productive, Sustainable and Resilient Global Agriculture and Food Systems; SUA: Nitra, Slovakia, 2018; pp. 275-287. [CrossRef]

58. Kubicová, L'.; Predanocyová, K. Situation in the market of bakery products. In International Scientific Days 2018; Wolters Kluwer ČR: Prahgue, Czech, 2018; pp. 391-406. [CrossRef]

59. Predanocyová, K.; Šedík, P.; Kubicová, L'.; Horská, E. Consumption and offer of organic food on the Slovak market. Acta Univ. Agric. Silvic. Mendel. Brun. 2018, 66, 1315-1323. [CrossRef]

60. Mach, J.; Dvořák, M.; Hošková, P. EU Milk and Dairy Market Changes and Impact of Globalisation Trends. In Globalization and Its Socio-Economic Consequences (Part III.-Economic Progress in Post-Soviet Countries) 10.10.2018; ZU-University of Zilina: Rajecke Teplice, Zilina, Slovakia, 2018; pp. 1204-1212.

61. Rybanská, J. Selected personality characteristics as predictors of emotional consumer behaviour. Eur. J. Bus. Sci. Technol. 2015, 1, 128-136. [CrossRef]

62. Rauová, E.; Bulanda, I.; Janková, G. Use of Social Networks in the Generation Z Demographic Segment. In Analýzy a Výskum v Marketingovej Komunikácii; UKF: Nitra, Slovakia, 2018; Volume 6, pp. 5-13.

63. Džupina, M. A Theoretical Study on Cross-National Differences o81: N Corporate Social Responsibility Orientation (CSRO). Eur. J. Sci. Theol. 2016, 2016, 163-169.

64. Smutka, L.; Svatoš, M.; Tomšík, K.; Džupina, O.I. Foreign trade in agricultural products in the Czech Republic. Agric. Econ. (AGRICECON) 2016, 62, 9-25. [CrossRef]

65. Polakevičová, I. Application of transactional analysis in marketing research-models of the hierarchy of effects of marketing communication and structural analysis. Prohuman 2015, 7, 1-10.

66. Kádeková, Z.; Nagyová, L'.; Horská, E. Role of public relations in the sustainability marketing in the Slovak agribusiness practice. In Challenges for the Agricultural Sector in Central and Eastern Europe; Agroinform Publishing House: Budapest, Hungary, 2014; pp. 57-70.

67. Gorski, H.; Fuciu, M.; Dumitrescu, L. Corporate social responsibility and marketing communication. Rev. Econ. 2016, 68, 86-106. Available online: https://www.researchgate.net/publication/308477186_CORPORATE_ SOCIAL_RESPONSIBILITY_AND_MARKETING_COMMUNICATION (accessed on 30 May 2020).

68. Holme, R.; Watts, P. Corporate Social Responsibility: Making Good Business Sense; World Business Council for Sustainable Development: Geneva, Switzerland, 2000; 32p. 
69. Porter, M.E.; Kramer, M.R. The competitive advantage of corporate philanthropy. Harv. Bus. Rev. 2002, 80, 56-69.

70. Creyer, E.H. The influence of firm behavior on purchase intention: Do consumers really care about business ethics? J. Consum. Mark. 1997, 14. [CrossRef]

71. Džupina, M. Podniková vízia, poslania a podnikové hodnoty, ako kl'účové komponenty strategického plánovania. Selye E-Stud. 2013, 4, 36-49.

72. Nagyová, L'.; Berčík, J.; Džupina, M.; Hazuchová, N.; Holotová, M.; Kádeková, Z.; Koprda, T.; Košičiarová, I.; Récky, R.; Rybanská, J. Marketing II; SUA: Nitra, Slovakia, 2018; 453p.

73. Nelson, L.R. Public Relations v odvětví potravinářského průmyslu. In Public Relations Řízená Komunikace Podniku s Veřejností; Caywood, L.C., Ed.; Computer Press: Bron, France, 2003; pp. 339-355.

74. Wiese, A.; Toporowski, W. CSR failures in food supply chains-An agency perspective. Br. Food J. 2013, 115, 92-107. [CrossRef]

75. Cheeseman, G.M. The Environmental Challenges and Opportunities Facing Food and Beverage Companies. Just Means. 2017. Available online: http://justmeans.com/blogs/the-environmental-challenges-andopportunities-facing-food-and-beverage-companies (accessed on 7 May 2020).

76. White, W. Social Responsibility's Influence over Food Safety and Quality. Food Safety Magazine. 2017. Available online: https://www.foodsafetymagazine.com/enewsletter/social-responsibilitye28099s-influenceover-food-safety-and-quality/ (accessed on 7 May 2020).

77. Melo, T.; Galan, J.I. Effects of corporate social responsibility on brand value. J. Brand Manag. 2011, 18, 423-437. [CrossRef]

78. Jiao, Y. Stakeholder welfare and firm value. J. Bank. Financ. 2010, 34, 2549-2561. [CrossRef]

79. Batat, W. The New Luxury Experience; Springer: Berlin, Germany, 2019.

80. Carroll, A.B.; Shabana, K.M. The business case for corporate social responsibility: A review of concepts, research and practice. Int. J. Manag. Rev. 2010, 12, 85-105. [CrossRef]

81. Harjoto, M.A.; Salas, J. Strategic and institutional sustainability: Corporate social responsibility, brand value, and Interbrand listing. J. Prod. Brand Manag. 2017, 26, 33. [CrossRef]

82. Jeong, K.H.; Jeong, S.W.; Lee, W.J.; Bae, S.H. Permanency of CSR activities and firm value. J. Bus. Ethics 2018, 152, 207-223. [CrossRef]

83. O'Brien, I.M.; Ouschan, R.; Jarvis, W.; Soutar, G.N. Drivers and relationship benefits of customer willingness to engage in CSR initiatives. J. Serv. Theory Pract. 2020, 30, 5-29. [CrossRef] 